\title{
Effective English Teaching for Young Learners Classrooms
}

\author{
Syafryadin \\ English Education Postgraduate Program, Bengkulu University \\ syafryadin@unib.ac.id
}

\begin{abstract}
Being a good teacher is a challenging thing. There are a lot of responsibilities that should be taken into account. The professional teacher requires continuous development; therefore, how to teach effectively so that the students can reach maximum learning achievement should be put as the highest priority for the teachers. However, it is assumed that it is not all teachers hold the principle. Some teachers just do the teaching as their routine or their job without any effort for developing their professionalism. It was discovered that most of English language teachers in Asia use grammatical-translation method as his or her teaching method (Paul, 2003). The teachers seemingly do not care much about the purpose of language learning itself and there is no real interaction in the classroom. It is assumed that the definition of a good teacher itself is still not clear and internalized well enough by the teacher since it seems every teacher has his or her own believes and perspectives to define what they are all about. There are many terms that tell what a good teacher is e.g. 'the successful teacher', the teacher I like best', 'the teacher I learn most from', and the like. Each of the terms delivers different meanings and tastes. In a more formal setting, simply, it can be argued that be a good teacher means be a good facilitator in the classroom, who plans, organizes, manages the instruction that is based on students' needs and characteristics so that the students can reach maximum learning achievement. In brief, this conceptual paper intended to identify effective teaching is weighed in the English classroom for young learners.
\end{abstract}

Keywords: Effective English teaching; good teacher; young learner

\section{Introduction}

Teaching is a complex process that requires careful organizing for its success. For this reason, teachers should realize the importance of managing for effective instruction, and classroom management should be considered as the highest priority. Nancy and Border (1991) stated that Effective instruction is the instruction that motivates students to learn affirms the presence a validity of diverse learning style maximizes the climate or conditions for learning in the classroom through the use of instructional design principles that value learning differences and increase the possibility of success for all students. Arranging effective teaching to create effective instruction is one of the teachers' responsibilities. To have effective learning, the teacher should be effective teachers, the students should be effective learners. Thus there are three aspects that should be taken into account: teachers' perspective, students' perspective, and learning process are considered the main aspects of effective teaching. What teachers define and how teachers implement the teaching in the classroom is much influenced by the student's success, therefore, teachers should have 
effective teaching in their classrooms. According to Kyriacou (2007), effective teaching is defined as the successful process of teachers to bring about the desired students learning by some educational activity. Moreover, Nancy and Border (1991) stated that effective teaching can be defined as the way of a teacher in giving the same opportunity to each of the students to be successful learners. From the definitions, it is obviously seen that there are three main variables of effective teaching i.e. the teachers, the students, and the learning activity itself.

In the terms of the teacher, effective teaching deals with the teacher's characteristics, The goals of effective language teaching may emphasize cognitive (intellectual-the language itself) aspects of the learning or affective (social, emotional, attitudinal, interactional) and physical aspects of learning (Bloom et.al 1956; cited in Kyriacou, 1997; Cameron, 2001; Pinter,2006; Paul, 2003).

Based on reviews of processproduct (Good and Brophy, 2003; Petty, 2006; Stronge, 2007; cited in Kyriacou, 2009) stated there are 10 Characteristics of effective teaching. The characteristics are teachers' clarity in explaining, how teachers create classroom climate, making use a variety of learning activities, establishing and maintaining momentum and pace for the lesson, encouraging students participation and getting all students involved, monitoring students' progress and attending quickly to their needs, delivering a well-structured and wellorganized lesson, providing students with positive and constructive feedback, ensuring coverage of the educational objectives, and making good use of questioning techniques. Therefore, to have effective teaching, a teacher should be able to integrate and implement the aspects into their teaching so that the students can reach maximum learning achievement.

The perspective of students, effective teaching deals with actively involving (Paul,2003; Cameron, 2001; Kyriacou, 2007) and meaningful learning (Pinter, 2006). Furthermore, Cameron (2001) stated that children are mentally active learners who will try to find meaning and purpose for activities that are presented to them. Actively involving learning means that the students should really experience step by step the learning process. The steps are Noticing, Wanting, Taking a risk, Experimenting, Succeeding, and Linking. They are considered as students centered learning. Furthermore, Gagne (Kyriacou, 2007) stated that the steps should have the three domains of learning i.e., cognitive, affective, motor skill learning domain. All the steps would be useless if they are not based on meaningful learning content. Meaningful is also called contextual. A lesson would be meaningful or contextual if it is reasonable for the students. The students know the reason why they should learn the lesson. The students do not only do what the teachers want to do. However, they relate the lesson to 
their life, surroundings, and peer knowledge.

From the perspective of learning activity, it is a must for the learning process is sequenced well, which means that it meets students' needs and characteristics. According to Paul (2003), the learning process should be sequenced from receptive to productive skills. The other theorists, i. e Cameron and Pinter hold the almost similar thing with Paul. Cameron (2001) stated that the learning process should be sequenced from Impersonal to more personal themes. In addition, Pinter emphasized that the sequenced should be from a concrete theme to an abstract theme.

\section{Discussion}

\section{Chris Kryiacou's framework for Effective Teachers}

According to Kryacou (2007), Effective teaching is indicated by the interaction that occurs in the classroom. In the framework, Kriacou focuses on seeing effective teaching from the perspective of the teachers. Kriacou listed there are 10 characteristics of effective teaching. The characteristics are teachers' clarity in explaining, how teachers create classroom climate, making use a variety of learning activities, establishing and maintaining momentum and pace for the lesson, encouraging students participation and getting all students involved, monitoring students' progress and attending quickly to their needs, delivering a well-structured and wellorganized lesson, providing students with positive and constructive feedback, ensuring coverage of the educational objectives, and making good use of questioning techniques. The characteristics actually lead the definition of effective teaching to the mutual respect and rapport between the teacher and the students. It is fact and often found in the classroom, that many students; misbehavior is often simply a reaction to ineffective teaching or behavior by the teacher that is felt unfair, which serves to undermine their respect for the teacher. The development of good rapport is based on three qualities in the teacher's interaction with the students: the teacher shows genuine care for each student's progress, the teacher shows respect for students as learners, and the teacher shows respect for students as individuals.

\section{David Paul's Framework for Effective Learners}

Different from Kryiacou, Paul's framework for effective teaching seems more focuses on seeing the quality of effective teaching from the perspective of students' characteristics. There are 6 stages are offered by Paul, which can indicate the effective teaching happens in the classroom. The stages are Noticing, Wanting, Taking a risk, Experimenting, Succeeding, and Linking. The noticing stage means the students notice new words or patterns while they are playing. In this stage, the students should be avoided to feel the 'learning' atmosphere. Rather than learning, they should feel the stage as playing activity. In this case, the 
students will easily absorb the lesson. The next stage is Wanting. Wanting means the students after noticing the words or patterns; they genuinely want to find out what is learned deeper. After that, the students go on to the stage of taking risks. Taking the risk stage is the stage when the students are likely to try the pattern that is learned. For instance, the students want to come forward to perform or act out the dialogue using the given expression. He or she just wants to try and brave to take the risk to be correct or wrong. After that, the students move on to the stage of Experimenting. Experimenting means the students can do a lot of activities where they play around with the new language target, trying things out, making mistakes, encountering many examples of the new pattern, and using it to express their own genuine feelings. Then, the stage is continued to the stage of Succeeding and then Linking. Succeeding means the students will be successful in understanding and using individual words and sentences if the new language target is at an achievable level. Whereas, Linking means the students are more likely to link the targets already learned into the mental model they are building up as they try to make sense of the world of English.

\section{Annamaria Pinter's and Cameron's Framework for Effective instruction}

Pinter concerned effective learning for the students. Pinter (2006) and Cameron (2001) emphasized that the quality of effective learning could be reached if the students find the learning process meaningful and fun as well. If the students find that they learn without any understandable reason or context, they would not find it is important or even internalize the lesson itself. Consequently, they would not learn best. It is assumed that Therefore, how to make the lesson meaningful (contextual) and fun, it should be seen as the important thing to be taken into account by the teachers. Children are mentally active learners who will try to find meaning and purpose for activities that are presented from them (Cameron, 2001).

\section{Synthesized Framework of Effective Instruction}

From the frameworks of effective learning that have already explained i.e. frameworks from Paul, Pinter, and Cameron, it is drawn a synthesized theory. There are three fundamental aspects of effective instruction i.e. effective teachers, effective learners, and effective learning process.

In terms of effective teachers, there are 10 characteristics of the effective teachers i.e. teachers' clarity in explaining, how teachers create classroom climate, making use a variety of learning activities, establishing and maintaining momentum and pace for the lesson, encouraging students participation and getting all students involved, monitoring students' progress and attending quickly to their needs, delivering a well-structured and wellorganized lesson, providing students 
with positive and constructive feedback, ensuring coverage of the educational objectives, and making good use of questioning techniques.

In terms of Effective learners, there are 6 stages that should be experienced genuinely by the students. The stages are Noticing, Wanting, Taking a risk, Experimenting, Succeeding, and Linking

In terms of effective learning, a teacher should be able to set an instruction that encourages its students holistically. Therefore, the learning activity in the classrooms should cover the whole aspect, not only demands the students to have knowledge but also demands the students to act actively and behave well. Because of that, the objective of a lesson should have various learning domains. Reiser and Dick (Reiser and Dick, 1996; Gagne, 1992, cited in Kyriacou, 2007) stated that the learning outcome of an objective should have four learning domains. The learning domains are knowledge skills, intellectual skills, motor skills, and attitude skills.

According to Reiser and Dick (ibid), the knowledge skill learning domain deals with the ability to recall and remember specific information. Operational verbs that usually stated in the objectives of a lesson plan are 'identify' or 'classify'.

Different from the knowledge skill learning domain, intellectual skill learning domain are those processes used by students that go above and beyond the pure memorization of information to the actual use of the information. Thus, it is graded from 'concept level', 'rule using level', and 'problem-solving level'. Concept level is a label used to describe a group of related things or ideas. A rule using level is a label used to describe combinations of concepts. Then, the problem-solving level is the highest level since it combines the rule using and asks students to act the rules. In the intellectual skills domain of learning measurable operational verbs occur if the objectives state verbs such as classify, apply, solve.

The next learning domain is the motor skill learning domain. This learning domain relates to the ability to act or perform the behavior. In terms of motor skills, operational verbs that should be employed are perform, execute, etc.

Then, in the aspect of attitudes domain of learning outcomes, a lesson plan objective should state operational verbs such as choose, etc, because this learning domain refers to someone's tendency to act or respond in a particular way with regard to the environment. These domains of learning outcomes also should be formulated in measurable verbs, because in the application, they should be able to be measured. In this case, all learning domains should be easy to be assessed by teachers. The domains of learning outcomes are listed in figure 2.2 as follows. 
Table 2.2 Suggested types of exercise in the classrooms for various Learning domains. Taken from Reiser and Dick (Reiser and Dick, 1996)

\begin{tabular}{|l|l|}
\hline $\begin{array}{l}\text { Domain of Learning } \\
\text { Outcome }\end{array}$ & $\begin{array}{l}\text { Types of } \\
\text { Activity }\end{array}$ \\
\hline Knowledge skills & $\begin{array}{l}\text { List, state, } \\
\text { describe, } \\
\text { recognize }\end{array}$ \\
\hline Intellectual Skills & $\begin{array}{l}\text { Classify, } \\
\text { apply, solve }\end{array}$ \\
\hline Motor Skills & $\begin{array}{l}\text { Perform, } \\
\text { execute }\end{array}$ \\
\hline Attitudes & Choose \\
\hline
\end{tabular}

The learning process will be successful if students' needs are accommodated by the classroom activities that are facilitated by the teachers. Therefore, how teacher as a facilitator is able to package a set of activities that maximize all students' potential becomes a fundamental aspect. Presumably, the problem occurs because teachers usually use a sourcebook for the instruction. On the other side, teachers cannot easily find good books as instructional resources. As a matter of fact, It is a shame to know that the one and the only resource of teaching activities in the classroom is only textbooks. As proved by Marsiti (Marsiti, 2008), Komariah (Komariah, 2008), and Hartiyana (Hartiyana, 2009) teachers usually depend on their instruction on what is stated in textbooks. They follow all textbook's activities. The worst, the textbook that most teachers use does not suitable for the students, because it is made in mass production and the contents do not meet students' characteristics. The most important principles of activities for students learning are equivalency between students' needs and characteristics and the activities created by the teacher as a facilitator. Some principles stated in one of British Council journals (cited in Damayanti et al, 2008) are explained below.

Effective teaching should have a sequence that suits students' needs and characteristics. A sequence is defined as the order in which the process of teaching and learning happens. The sequence that moves from easy to difficult task, for example, an impact on the students learning achievement. Their level achievement will adjust simultaneously to the level of task that is given. According to Cameron and Pinter (2006. cited in Damayanti et al, 2008), a good sequence of teaching and learning activity has four principles: it moves from receptive skills to productive skills, from controlled to less controlled, from impersonal to personal, and from concrete to abstract.

The sequence that moves from receptive skills to productive skills means that before students are able to produce the language, they should absorb the language first (Pinter, 2006). It is a perfect phase in language learning since its mastering demands comprehension skills of the language.

The sequence that moves from controlled to less controlled means that the teaching and learning process in the classroom not only asks students to be excellent in the English subject but also asks them to be 
independent. Being independent is very important because learning is not the process that is indicated only by instruction from the teacher and then the students follow what has been instructed, but learning is a matter of an endless process that demands someone to be autonomous to learn everything for the sake of study forever. Besides, the role of teachers here is as a facilitator not as a source of learning activity, so that is why the learning activity should be ordered from controlled activity to less controlled activity.

The sequence that moves from impersonal to personal means that the teachers as the facilitator should always do the apperception phase in teaching and learning activity in the classroom that uses object or theme, which is general or impersonal to personal. It is aimed at actively involving the students in the material that will be given.

The sequence that moves from concrete to abstract implies that teaching and learning activity in the classroom should be ordered from abstract to concrete. The abstract means that teachers should maximize concrete activities. Such as 'let's see the magazines', 'let's touch your nose', etc, It is a must since the students are in the stage of preoperational. As insisted by Piaget (Pinter, 2006) that in this stage, the children will learn maximally if the activities in the classroom are held concretely. Then, it is moved to the abstract. In line with their growth and their development stages that change to the formal stage that the students learn more abstract in learning. As insisted by Pinter (cited in Weigand, 1977), the stage of Formal Operations beginning at 11 to 12 years of age. The following is the explanation. The individual in the stage of formal operations learns to manipulate symbols and to deal with ideas verbally without always having to work directly with physical objects. In other words, students become able to think in increasingly abstract terms. The individual in this stage also learns to think about consequences and implications.

\section{Young learners' Characteristics}

As has already pointed out, to have effective teaching that results in effective learning achievement, teachers should base all the aspects of their teaching to the needs and characteristics of the students. In this case, the students are young learners of fourth are junior high school students. According to Piaget (Pinter, 2006), The age of 12 (eight graders of junior high school students) is categorized into young learners age, specifically, it belongs to the group of the formal operational stage. Therefore, knowing their characteristics is considered crucial. The following are the characteristics of young learners.

There are numerous experts that offer theories of young learners' characteristics. For example, Pinter (2006) stated that young learners learn through playing. It means that teachers should be able to create a fun atmosphere in the classes so that the students can enjoy the lesson. 
However, fun is not enough. The lesson for young learners also should be meaningful. As stated by Cameron (2001) that young learners actively construct meaning from their experiences. Having this characteristic, young learners are too valuable to be given fun lessons only. The teacher should avoid teaching for no obvious reason. According to Hartiyana (Hartiyana, 2009) Sometimes, teachers only want their students to speak English without any meaning or reason for what is the function of doing this. Another characteristic shows that young learners have great curiosity.

Pinter (2006) proved that young learners have a great curiosity to try new things and exploring concrete and abstract things. The teachers should accommodate their curiosity with many activities. What have explained above are some characteristics of young learners, the following are listed more characteristics according to Pinter (2006) in the table below.
Table 1

Young learners' characteristics

Adapted from and Pinter (2006)

\begin{tabular}{|l|l|}
\hline No & Characteristics \\
\hline 1 & $\begin{array}{l}\text { Children need space for } \\
\text { language growth }\end{array}$ \\
\hline 2 & $\begin{array}{l}\text { Children language learning } \\
\text { depends on what they } \\
\text { experience }\end{array}$ \\
\hline 3 & $\begin{array}{l}\text { Children actively try to } \\
\text { construct meaning }\end{array}$ \\
\hline 4 & $\begin{array}{l}\text { They are more concerned } \\
\text { about themselves than other }\end{array}$ \\
\hline 5 & $\begin{array}{l}\text { They enjoy } \\
\text { imagination, and movement }\end{array}$ \\
\hline 6 & $\begin{array}{l}\text { They have lower levels of } \\
\text { awareness about themselves as } \\
\text { language learners as well as } \\
\text { about process of learning }\end{array}$ \\
\hline 7 & $\begin{array}{l}\text { They have limited reading and } \\
\text { writing skills even in their first } \\
\text { language }\end{array}$ \\
\hline 8 & $\begin{array}{l}\text { They understand meaningful } \\
\text { messages but cannot optimal } \\
\text { analyze language yet. }\end{array}$ \\
\hline
\end{tabular}

Knowing and understanding all the characteristics will be influenced by the effectiveness of the instruction. At this point, all the characteristics should be the necessary part of planning a lesson for young learners that will be brought in all the aspects of the learning activities in the classroom.

\section{Conclusions}

Teaching is a very valuable profession. The profession requires high-quality teachers i.e. teachers who are not only smart but also wellplanned. Teachers need to have the 
ability to plan and organized the lesson effectively. The quality of effective instruction can be reached if both of the teachers and students could coordinate to make the learning process experienced effectively. The teachers are considered effective teachers when he or she fulfills the 10 characteristics (Kryiacou,2007). The characteristics are: teachers' clarity in explaining, how teachers create classroom climate, making use a variety of learning activities, establishing and maintaining momentum and pace for the lesson, encouraging students participation and getting all students involved, monitoring students' progress and attending quickly to their needs, delivering a well-structured and wellorganized lesson, providing students with positive and constructive feedback, ensuring coverage of the educational objectives, and making good use of questioning techniques Then, in terms of the students, the students are considered effective learners when he or she fulfills the 6 stages of their learning. The stages are Noticing, wanting, Challenging, Playing, Succeeding, and Linking. Then in terms of the process, learning is considered effective learning when fulfilling some aspects. The aspects are the learning should be sequenced from receptive to productive skills, from impersonal to personal, from concrete to abstract, from fully controlled to less controlled, and to informal to formal theme activity. Besides, the learning itself should present the four learning domains of learning: Knowledge skills, intellectual skills, Motor skills, and attitudes.

Furthermore, related to effective teaching, teachers need improvement in how to organize the instruction best. The teachers might have problems in formulating lesson plans in their day-to-day practices. Presumably, the problem might be due to inaccessible information or discussion of how implementing effective instruction or even the teachers themselves did not adequately proactive to improve their ability to organize the lesson effectively so that the possibility of all students to be the successful learners can be reached easily.

\section{References}

Damayanti, I.L. et. Al (2008). Analisis Relevansi Mata Kuliah English for Young Learners dengan Kebutuhan Pembelajaran Bahasa Inggris di Sekolah Dasar: Bandung: Universitas Pendidikan Indonesia. Unpublished paper. Hartiyana,P.(2009). Child-Centered Method in Teaching English to Young Learners. Bandung: Universitas Pendidikan Indonesia. Unpublished paper.

Komalaningsih, R. .U (2009) English Textbook for Young Learners Used in Twenty-five Primary Schools in Bandung Kulon: Universitas Pendidikan Indonesia. Unpublished undergraduate thesis.

Kyriacou,C.(2009). Effective Teaching in Schools: Theory and Practice. United Kingdom:Nelson Thornes Ltd. 
Lang,H.R and Evan S,D.N (2006) Model,strategies and Method for Effective Teaching. Boston Pearson Education,inc.

Marsiti, I. S. (2009). Assessment Techniques Administered in English Language Classroom for Young Learners. Bandung: Universitas pendidikan Indonesia. Unpublished paper.

Paul,D.(2003). Teaching English to Children in ASIA. Quarry Bay: Longman ASIA ELT

Pinter,A.(2006). Teaching Young Language Learners. Oxford: Oxford University Press.
Reiser, R. W. Dick (1996). Instructional Planning: A Guide for Teachers. Massachusetts: Allyn and Bacon. Richards, J. C and Rogers, T. S (1986) Approaches and Methods in Language Teaching: A description and Analysis. New York: Cambridge University Press.

Weigand,J.(1977).Implementing Teacher Competence: Positive Approaches to Personalizing Education. New Jersey:Prentice-Hall. Jakarta: Andi Jakarta. 